\title{
Robust Army Aviation in Nepal for Services to the Country, People and Organization
}

\section{Man Bahadur Karki}

\begin{abstract}
Aviation is an essential mode of transport service because of the mountainous terrain in Nepal. Different parts of the country cannot be connected through a wide range of road network. Further, Nepal's diverse geographical features, ranging from high hills to low wetlands appropriate airport transport. Nepal Army Aviation unit has immensely contributed to the organizational operational flights, emergency aerial rescue, relief, humanitarian services and nation's development with the limited resources and infrastructure during its fifty-five years of journey in the air. After the adoption of liberal sky policy by the Government of Nepal in 1992, the private airlines commenced commercial air operations. Prior to this Nepal Airlines and Nepal Army Aviation unit were only the two entities operating inside the domestic airspace of Nepal. Despite the number of private air operators, there are still not enough and abundantly available air assets to fulfill all the requirements of air services especially in emergency aerial rescue, quick disaster response humanitarian assistance and relief flights in a short notice. Furthermore, there is a scope for the civilmilitary partnership in the civil aviation field for the Nepal Army Aviation. This article, in efforts to make the Army Aviation agile,
\end{abstract}

nimble and adoptable force multiplier for enhanced national security, examines its contributions in the service of country, people and organization as a state-owned institution with supports from secondary data.

Keywords: Air transportation, Nepal Army Aviation, civil aviation, state owned aircraft Introduction: Prospect of Aviation Industry in Nepal

Aviation is an equally essential mode of transport in Nepal. Because of its diverse geographical features, infrastructures and geo-strategic position, air transportation can best serve Nepal for its security and connectivity. Air transportation has an inherited advantage of speed, height and flexibility to carry out the tasks through effective utilization of air assets. When there is a need for service in a short notice and regular transportation of passengers, cargos, logistics services, special and other flights at the normal and emergency, aviation is the most effective mode of transport. Despite fast growth in private air operators in Nepal, there still lack abundant air assets to provide quick aerial rescue, relief, humanitarian and special flights. Precisely, there is a tremendous prospect of partnership opportunity for the Nepal Army Aviation to collaborate with the civil aviation in order to promote tourism and strengthen economy in the country. 
In the history of aviation in Nepal, 1949 $\mathrm{AD}$ is considered a beginning of aviation operations in Nepal with the landing of Indian Ambassador Mr. Sarjit Singh Mahathia fourseater single engine Beechcraft Bonanza flight at Gauchar, Kathmandu (KC, 2020, np). This official flight opened a new avenue to start Himalayan Aviation Dakota chartered flight from Kathmandu to Kolkata, India. Within a few years of charter service, then Royal Nepal Airlines Corporation (RNAC) began domestic and international scheduled flights from July 1958. Likewise, various domestic airports were constructed to expand domestic networks for the RNAC commercial flights home and also expanded in the international routes with this national flag carrier.

Within less than a couple of decades, Royal Nepalese Army Airborne Transport Support Wing was established in 1965 with the three Twin Pioneer aircraft gifted by the British Government to start troops transportation, rescue, cargo and operational needed flights. In the subsequent years, the name of this wing changed with various names and finally expanded at the level of Directorate General of Army Aviation (DGAA) in April 2010. DGAA comprises flying bases of Mid Air Base, Western Air Base, V/VIP Flight Service, Maintenance Service and Training Center.

After the Government's adoption of the liberal sky policy in 1992, the private sector started to invest in the aviation industry in Nepal. Such liberalization opened another chapter and expanded aviation services through private investment in the aviation industry. This policy attracted the investors to start fixed wing (airplane) and Rotary Wing (helicopter) operations. Rotary wing service is mainly on the charter basis, whereas the fixed wing started the scheduled commercial and charterservices in various regions of the country. As of now there are four fixed wing airlines operating international sector and nine airlines in the domestic sectors. Likewise, ten rotary wing companies and four recreational (Ultralight) companies are operating in the development of air transportation in Nepal (CAAN, 2020, p. 1).

Prior to the entry of private commercial operation in the aviation industry in 1992, there were only two Government entities operating inside the domestic airspace in Nepal. Those were the Nepal Army-owned aircrafts and Nepal Airlines commercial aircrafts. Nepal Airlines was rendering mostly the commercial scheduled and chartered flights by the fixed wing in the various airfields. Whereas another state-owned entity, Nepal Army Aviation was rendering the services with the fixed and rotary wing across the country for the transportation of developmental goods, emergency rescue, relief, transportation of V/ VIP passenger and other miscellaneous works on charter basis as per the Commercial Flight Development Committee Order 2036 BS (Byaparik Udan Bikas Samiti Gathan Aadesh 2036). ${ }^{1}$ Some of these commercial flights transported turbine, parts of suspensionbridge, and daily use commodities to remote areas. They would also deliver food items, including salt, rice, oil, noodles and lentils. In the meantime, those airlines could carry constructions materials, such as rod, cement, iron, steel and solar power panels. Likewise, those carriers delivered fuel and vehicles to rural parts across the hilly region of Nepal at the request of Government, non-

1 According to Commercial Flight Development Committee Order 2036 fifty percent of the amount collected from the charter flight goes directly to the national revenue and the remaining fifty percent will be used for the maintenance, procurement of spares and training of the crew. 
governmental and international organization. Likewise, there was regular charter service requested by Nepal Food Corporation and Salt Trading Corporation to transport daily commodities, such as rice and salt in the Mid-Western and Far Western region where the road connectivity was very limited. In this situation, air was considered the most feasible option. In this period, other entity aircrafts were rendering commercial passengers and limited cargo flights in domestic and international sectors, including the Very/Very Important Personnel (V/VIP) official abroad trips.

The frequency of the civil support flights to Nepal Food Corporation and Salt Trading Corporation decreased in Nepal Army Aviation as the private airlines with fixed and rotary wing aircraft started their commercial operation from 1992. Nonetheless, there are still several requests made at the army aviation for air services of emergency aerial rescue, Search and Rescue (SAR) service to civil aviation, transportation of construction materials, explosive for construction of road, sling operation and V/VIP chartered service. At times, it is taking more than one day to locate and recover the lost aircraft. Other times, there are several premature death of pregnant women without health facilities in the remote villages and delay in providing aerial rescue flights, lack of air resources during the monsoon season or at other human induced and natural disaster to provide swift aerial response, transportation of fuel, bitumen, explosives in the various regions of the country for road, hydropower construction work, transportation of critical medical equipment and medicine during the epidemic and pandemic, support flights to sister security forces, federal and provincial government flights and so on. Therefore, it clearly vindicates the utilization and importance of state owned air assets to render service not only confined to the organization, Nepal Army but to the country and people too.

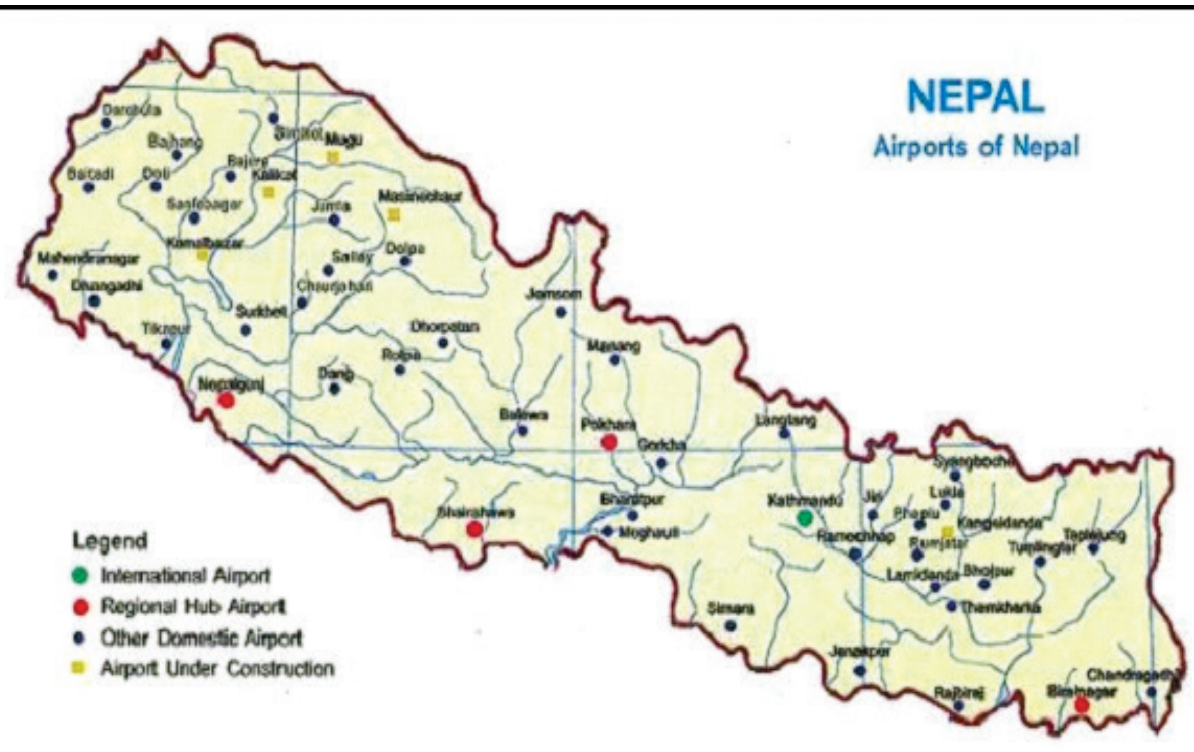

Fig.1 Airports of Nepal (Source: https://www.guthi.net/nepalatc/airports.html\#15.\%20Bhojpur) 
Army aviation is the state-owned aircraft deal in Army assets is investment in the national assets to strengthen and promote national security of the country. Air assets are costly to procure, operate and sustain its operation. However, it has got several advantages and is indispensable for every country. For that reason, Bhandari claims that Army aviation "should not be considered as a costly burden in times of peace and important at the time of threat or war" (Bhandari, 2009, p. 3). The more we equip, maintain, expand, improve, train and modernize the army aviation, the more the country can reap. In that condition, the country can serve the public better. Moreover, Nepal Army force projects its military capability while strengthening national security through the robust Nepal Army Aviation.Various Types of the Civil and Military Flight Operations

Army aviation assets are capable enough to carry out multifaceted tasks. Assets are easily convertible to provide immediate services from one role to another as per the need. It has been providing multiple civil and military flight operations to the people, organization and country since its inception-be it at the normal time or troubled time or disaster with the limited available resources.

\section{Army Operational and Tactical Flights}

Army Aviation primarily aims at carrying out the strategic, operational and tactical needs of the organization in the normal, conflict, disaster and emergency round the clock seven days a week. Transportation of troops, cargo, resupply, casualty/medical evacuation from field or transfer to the better medical facilities, close air support, night vision goggles (NVG) flights, slithering/hoisting operation, insertion and extraction of the troops, combat search and rescue, training, V/VIP flight, aerial reconnaissance and surveillance, show of force, deterrence, battle casualty evacuation from the front line, communication flights, observation and correction of the artillery fire and so on are the key operational and tactical flights of the robust Army aviation.

\section{V/VIP Flight Service}

Some of the air assets are registered as per the Nepal Civil Aviation Regulations (NCAR). These assets are maintained, operated and regulated in accordance with the prevailing civil aviation act, regulations and standards. This legal provision offers the Nepal Army Aviation opportunities to serve the people and organizations for the operational needs at their request. There is a lack of multi engine helicopters choice from the civil operators when the international organization and diplomatic mission at times opt to charter the multi-engine helicopter. Only the Shree Airlines has Mi-17 helicopter, rest another nine helicopter companies are operating with the single engine helicopter (CAAN Report, 2020, p. 46). Therefore, army aviation as a state-owned asset is a choice available for important service with the ranges of helicopters option in civil and army configuration. In most of the V/ VIPs President, Prime Minister or Foreign Dignitaries official visits to the country army aviation civil version helicopters are being used.

\section{Para Jump/Supply Drop}

One of the other main operational activities is parachute jump, supply drop, jump master and path finder training. These activities are only possible through Army air assets. Both the fixed wing and rotary wing are capable of carrying out this unique role. During the 2015 Earthquake in Nepal, aerial supply drop was proven essential after the onset of earthquake 
in providing relief items where the helicopter could not land due to the limited space or obstacles.

\section{Cargo Transportation}

Transportation of foods, medicines, construction materials, bitumen, solar energy, iron-rod, steel, zinc sheet, plywood and so on are the materials being flown on cargo flights request from the Government and non-governmental agencies after the approval from the Army HQ level. These types of flight are carried out when the civil airlines are unavailable enough to execute these tasks. Additionally, there is a lack of aviation fuel at theremote airfields where the pre-positioning of aviation fuel is required for the multiple sorties for the civil helicopters. For instance, in Simikot to carry out the helicopter multiple
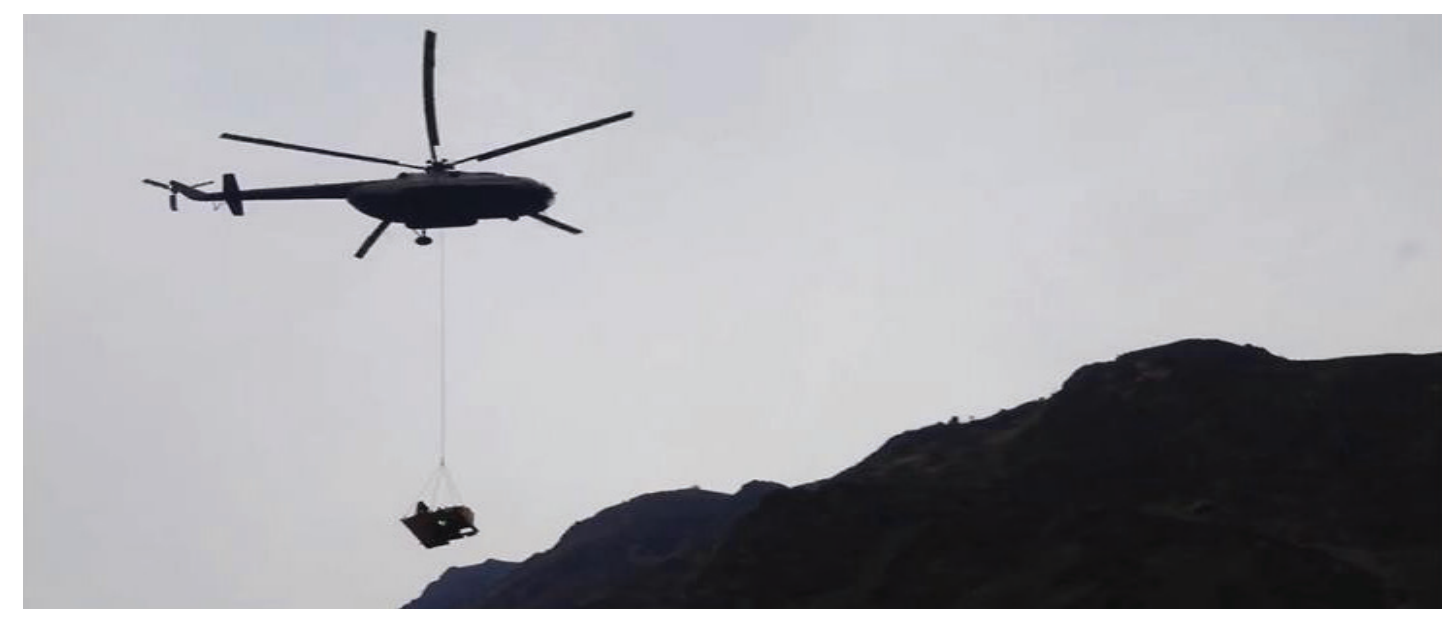

Fig. 2 Mi-17 Underslung/Sling operations (Source: https://www.dailymotion.com/video/x2y3ijy)

\section{Search and Rescue}

Search and Rescue (SAR) operation is an obligation of Civil Aviation inside the national airspace. Upon the request from Civil Aviation, SAR mission flight is carried out to locate, identify and trace the whereabouts of the aircraft and if need be sorties to Kailash Mansarovar or multiple shuttles from Lukla to Everest Base camp required preposition of aviation fuel at the nearest airfields.

\section{Sling/Underslung Operation}

Sling operation is a kind of service on which the heavy and odd size loads that cannot accommodate inside the fuselage of aircraft are airlifted from one place to another. Normally, distance is a short but a topographical barrier to transport by means of road is inconvenient. For instance, moving heavy turbine machines for the hydroelectricity dam construction, transporting other heavy equipments, such as dozer, excavator, tractor, pick up van, generator and fuselage of aircraft for maintenance are few examples of underslung operations being carried out to assist in developmental works and economic growth. to provide rescue operations. SAR mission is launched immediately. When the aircraft fails to provide position report for more than thirty minutes, aircraft lost procedure starts. Additionally, to search the lost mountaineers or trekkers in the high hill upon request from charter parties or Government Agency this type of flight will be performed. 


\section{Ceremonial Flights}

On the regular basis during the Maha Shivratri and Army Day, Democracy Day, Constitutional Day, Fulpati festival flower showering (Puspa-bristi) and banner display flights are launched. In addition to these, in other special occasions such as South Asian Federation (SAF) Games in 1998, Exercise Shanti Prayas-I at Birendra Peace Operations Training Center (BPOTC) Panchkhal in 1999 banner display and free-fall jump were carried out too.

\section{Foreign Dignitaries Special Flights}

For the V/VIP transportation, it is recommended to use multi-engine air assets. Thanks to the Government, most of the air assets in Nepal Army are multi-engine (aircraft with more than one engine). In multiengine aircraft, in case a single engine fails, with the help of another running engine can take the passenger, cargo or payload safely to the nearest safe location or destination. Additionally, if there is not enough air assets in the country, foreign dignitaries may bring their own assets to fly inside the domestic routes during the official visit. Therefore, the Government needs to give due priority and support the Army to equip it with quality and proven air assets. Following are some of the key foreign dignitaries' special flights completed on army air assets.

1. In November 2014 during the South Asian Association of Regional Cooperation (SAARC) Summit army aviation provided the air patrol and special flights for retreat and dignitaries visit to Lumbini, Nepal.

2. Kathmandu to Pokhara and return flights of participants of SAARC 37th Session of the Council of Ministers in March 2016.
3. During the visit of the United Kingdom Prince Harry to the various locations of Nepal in March 2016.

4. During the visit of the United Nations under Secretary General, Department of Peacekeeping and Operations (DPKO) Mr. Jean Pierre Lacroix in June 2018.

5. During the President of the People's Republic of Bangladesh Md. Abdul Hamid goodwill visit to Nepal in November 2019 6. Nepal's head of state, head of government and Army chief official visit to South Asian regional countries India and Bangladesh at various times, fixed wing aircraft (Avro/Skytruck) were utilized. Recent example is the Chief of Army Staff General Purna Chandra Thapa official visit to Bangladesh 12-15 January 2020.

7. Employment of air assets for mountain flight, visit to various heritage and tourist destinations such as Muktinaath, Lumbini, Pokhara, Hotel Everest View, Namche and so on during the friendly countries Army Chiefs and high dignitaries official visit to Nepal at the multiple time.

\section{Disaster Rescue and Relief Flights}

Every year Nepal experiences various types of natural and human induced disasters such as earthquake, floods, fire, landslide, cold/ heat wave, thunderbolt, glacier outburst, air and road accidents, epidemic and so on. In terms of disaster vulnerability to earthquakes and floods Nepal ranks 11th and 30th respectively in the world. Diromg the 2017 and 2018 period, a total of 6,381 small and large disaster incidents reported that claimed 968 deaths and 3,639 injuries (MOHA, 2019, p. 4). There is a provision for Nepal Army's role on disaster management according to 
the Constitution of Nepal 2015 article 267. As a prime responder of disaster in order to provide swift and efficient rescue, relief and rehabilitation/reconstruction flights, army aviation carried out countless number of disaster related rescue and relief flights till now. Few of them are as follows: On 31 July, 1992 Thai Airways international flight TG 311 crashed at Ghyang Phedi, Rasuwa army air assets deployed for the Search and Rescue (SAR) and recovery flights.

1. Record breaking mountaineering rescue operation of Ecureuil helicopter from the Camp 1 Mount Everest at an altitude of 19200 feet on 15 May 1995. Indomitable courage and extraordinary skills of the pilot managed to rescue two mountaineers. This is the recording breaking flights made by the Ecureuil helicopter.

2. In November 1995, Army mobilized air assets to evacuate more than five hundred people to rescue people who were stranded due to sudden heavy rainfall and landslide in the western part of Nepal, Manang.

3. Nepal army Avro aircraft transported relief materials to Bhuj, India and Lahore, Pakistan in Bhuj Earthquake 2001 and Pakistan Earthquake 2005 respectively.

4. On 23 September 2006, Shree Airlines Mi-17 helicopter crashed at Ghunsha, Taplejung army air assets were deployed to locate the crash site and recovery. Illfated helicopter crash site was managed to locate only on 25 September 2006.

5. During the floods in Koshi, MidWestern and Far Western Region in 2008, various army air assets deployed for the aerial search and rescue, rescue and relief operations. (NA, 2020).

6. Army air assets evacuated stranded foreign and national passengers from
Lukla in November 2010. There were more than 2000 passengers stranded due to the bad weather hampered commercial flights for a few days (Becker, 2010).

7. In Nepal Earthquake 2015 army assets were extensively employed for initial Search and Rescue, immediate rescue, relief and recovery flights in the various parts of the country. Command centers were established in Kathmandu and Pokhara for the effective mobilization and employment. With the limited number of Nepal Army helicopters transported more cargo than the multi-nations helicopter in rescue and relief operations.

8. In the first week of July 2018, stranded Indian pilgrims were evacuated from Hilsa to Simikot and Simikot to Nepalgunj by using civil and army air assets. There were 1430 Indian pilgrims who were stranded while returning from Kailash Mansarovar due to the bad wea ther. (PTI News dated 04 and 07 July 2018)

9. A pregnant woman who was at risk after she was unable to give birth to her baby was airlifted from Puthauttatganga, Rukum to Nepalgunj by a Nepal Army helicopter on 02 January 2020. (The Rising Nepal, 2020)

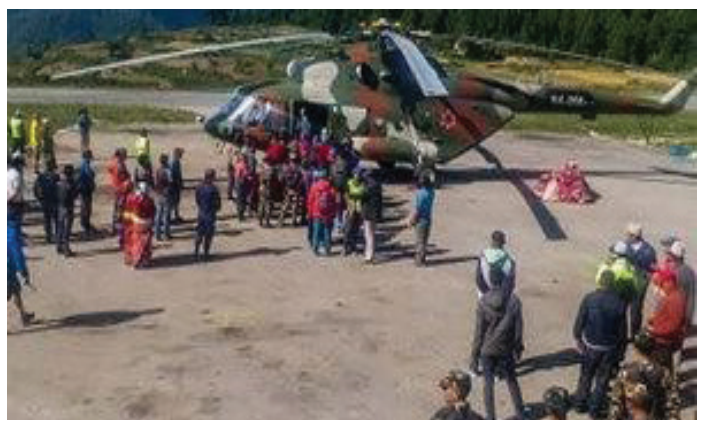

Fig. 3 Nepal Army Aviation Mi-17 at Simikot Airport to rescue stranded Indian Pilgrims (PTI: 2018) 
Nepal Army Aviation Various Services in Pictures

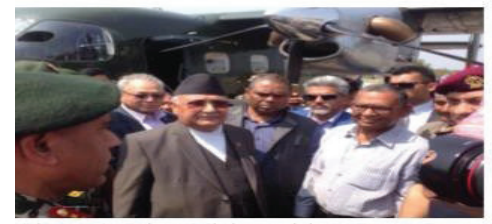

Picture 1: Prime Minister visit to Bara - Parsa disaster (wind-storm) stricken area in April 2019

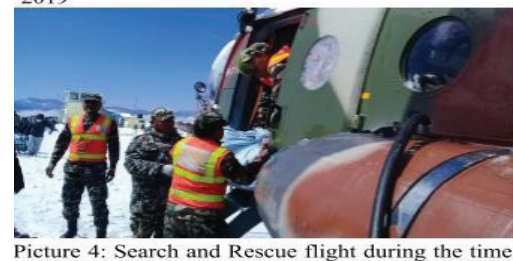
Picture 4: Search and Rescue flight during the tim

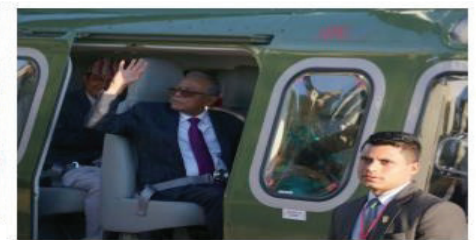

Picture 2: Special flight of Bangladesh Presiden during official visit in November 2019

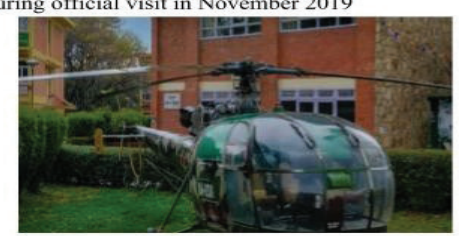

Picture 5: Alouette Helicopter handed over to Picture 6: Preparing flight to Jumla ts Institute of Engineering, Pulchowk Campus transport medical equipments and collec for Study and Research

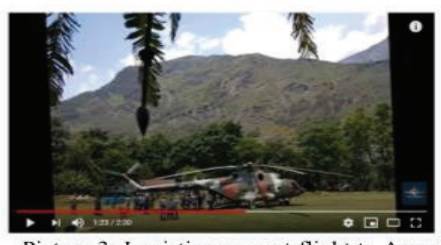

Picture 3: Logistics support flight to Armed Police Force at Darchula

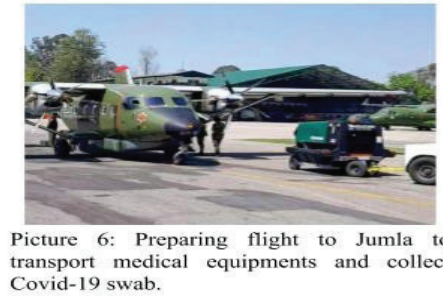

Fig. 4 Nepal Army Aviation various services in pictures

\section{Support to the Sister Security Forces}

At the request from sister security forces Nepal Police (NP) and Armed Police Force (APF), army assets provided services for emergency rescue, logistics support and operational support flights. Recent example is to establish APF Border Out Post (BOP) at Chhangrul, Darchula. In the past at the time of insurgency period 1996-2006, army air assets were used for the rescue, logistics and operational support for both the forces.

\section{Civil Military Partnership}

\section{Army Aviation Assets Handed Over to Pulchowk Campus and Narayanhiti Museum}

Nepal Army handed over used air assets which had completed useful life and declared as Beyond Economic Repair (BER) air assets to educational institution, museum and training school. This will promote civil - military partnership, military commitment to support and encourage young minds to explore innovation, creativity and research work in the field of science and access to the public viewers. Nepal Army registration NA-
030 (Alouette helicopter) decommissioned light utility helicopter was handed over to the Institute of Engineering (IOE), Pulchowk Campus on Feb 12, 2020 whereas Nepal Army registration NA-20 (Avro airplane) was also handed over to Narayanhiti Museum, Kathmandu. Prior to this RAN-19 (Skyvan airplane) was on public display at Army Museum, Chhauni. Partnership between Civil Aviation Authority and Army Aviation

There is no separate and independent air traffic service established by the Army Aviation. For the safe, efficient, reliable and timely separations of traffic, communication and navigational service Nepal Army entirely uses Nepal Civil Aviation Authority facilities and services. Even during the troubled be it in conflict or disaster the Civil Aviation has provided vital Air Traffic Service (ATS) to maintain safe operations in the Nepalese domestic airspace.

\section{Search and Rescue}

Civil Aviation Requirement for Search \& Rescue (CAR-12) 2.1.1 document states Civil Aviation Authority of Nepal (CAAN) is responsible for establishment and provision 
of search and rescue services within Nepalese territory in coordination with other agencies to ensure that assistance is rendered to persons in distress. Such services shall be provided on a 24-hour basis. Likewise, two more international airports - Gautam Buddha and Pokhara - are starting operations in future. Nepal Army Aviation is a reliable service provider and state owned aircraft which has participated in almost all of the major air accidents in Nepal. Its staff is also a permanent member of the Rescue Coordination Center (RCC) and participated in the number of accident investigation boards.

\section{National Civil Aviation Security Committee}

Nepal Army representative is also a member in the numbers of Civil Aviation Committee. To name few but not limited to Rescue Coordination Committee, Tribhuwan International Disaster Response Committee, Airport Emergency Plan and National Civil Aviation Security Committee for the safe, efficient, orderly, reliable and cost-effective air services and tourism promotion in Nepal.

On 24 December 1999, Indian Airlines IC 814 with 176 passengers and 15 crew aboard scheduled flights from Kathmandu to New Delhi was hijacked. The hijacked Airbus A300 was taken to Kandahar, Afghanistan. It took about a week to resolve the case. In August 2005, Austrian registered Jet chartered flight bound to New Delhi from Guhati (Aasam), India entered to Nepalese Airspace via Tumlingtar without any permission from Nepal. The aircraft was force landed at Tribhuwan International Airport (TIA), Kathmandu due to the unauthorized intrusion inside the Nepalese airspace and safety of other traffic. After the fact finding and investigation of this incident, the aircraft was released.
In cases like these, the National Civil Aviation Security Committee which is the highest body chaired by the Minister/State Minister of Tourism and Civil Ministry level will be activated and provide a decision through the Committee or Subcommittee as deemed necessary.

\section{Way Ahead to Augment Nepal Army Aviation Expansion of Air Base to East and West}

Presently there are three flying bases i.e., Mid Air Base (MAB), Kathmandu, Western Air Base (WAB), Surkhet including V/VIP Flight Service at Kathmandu. Thanks to the current leadership to formally inaugurated the Western Air Base, Surkhet on 03 September 2019. The WAB requires equipping with a full number of assigned assets, infrastructure, equipment and manpower at the earliest. In the same way, Eastern sector to cover Province No. 1 and some of the areas of Province No. 2, Eastern Air Base (EAB) is equally quintessential to provide quick, reliable, efficient air Service to address the present operational requirement in the changed context and handle the future challenges.

\section{Deep Level Maintenance Facility}

Present Repair and Maintenance Service should be upgraded with the modern hangar and state of the art technology so that it can repair and maintain the current fleets of Army aviation in Nepal so as to save foreign currency going abroad. It should be capable of doing deep level maintenance such as overhaul of the medium and heavy category of fixed wing and rotary wing independently in Nepal. 
Structural Adjustment with the Modern Aircraft and Logistics

Army Aviation should be regarded as Combat Supporting Arms similar to Signal, Engineering, Artillery, Air Defense and Armor. It should not be considered the Combat Support Services because of its operational capabilities at the front line, force multiplier and lessons learnt from the past operations. Around 450 aviation personnel, including the security staff are providing unwavering services to the country and countrymen. This strength is very low once its operational footprint expands outside the capital. At the time of expansion of Air Bases, due consideration also needs to be given on increasing its strength and equipping modern aircraft with the latest technology, infrastructure, quality and environmentally friendly assets.
All types of aircraft are not suitable to operate in Nepalese remote airfields as there are maneuvering restrictions of one-way approach i.e., land from one direction and take off from opposite direction at the Short Take Off and Landing (STOL) airfields. In some of the STOL airfields fixed wing aircraft are required to call off the operations in the afternoon due to the strong surface wind, turbulence or low visibility. Normally, the fixed wing operating cost is less, speed is higher, payload (carrying capacity) is more and easy to maintain than the rotary wing helicopter. In this uniqueness of operations in Nepal, right balance and composition of fixed and rotary wing aircrafts in the Nepal Army Aviation is necessary for efficient, reliable and cost-effective utilization.

Table - 1 Aircrafts in Nepal Army Aviation

\begin{tabular}{|l|c|l|l|}
\hline Type of Aircraft & Quantity & Manufacture Country & Remark \\
\hline \multicolumn{4}{|c|}{ Fixed Wing (Airplane) } \\
\hline CN-235 & 1 & Indonesia & \\
\hline Skytruck & 3 & Poland & \\
\hline Islander & 1 & United Kingdom & \\
\hline Piper Trainer & 2 & United States of America & \\
\hline \multicolumn{4}{|c|}{ Rotary Wing (Helicopter) } \\
\hline
\end{tabular}

\begin{tabular}{|l|c|l|l|}
\hline Mi-17 & 4 & Russia & \\
\hline Ecureuil & 3 & France & \\
\hline Lancer & 2 & India & \\
\hline $\begin{array}{l}\text { Advanced Light } \\
\text { Helicopter (ALH) }\end{array}$ & 1 & India & $\begin{array}{l}\text { Bell 206-2 in Civil \& Bell } \\
407-1 \text { in Army Version }\end{array}$ \\
\hline Bell & 3 & United States of America & $\begin{array}{l}\text { in Civil \& 1 in Army } \\
\text { Version }\end{array}$ \\
\hline Agusta 139 & 2 & Italy & \multicolumn{2}{|l}{} \\
\hline
\end{tabular}


While procuring the aviation materials, the concerned authority should be able to streamline the fleet of the aviation, installations of standard and optional special equipment and instrument, such as firefighting capability (bumbi-basket), emergency aerial evacuation set, hoisting/underslung, Cockpit Voice Recorder (CVR), Flight Data Recorder (FDR), Enhanced Ground Proximity Warning System (EGPWS), Traffic Collision Avoidance System (TCAS), aircraft automatic tracking system and logistics guarantee at least for the year. This will also help to save the money in terms of training, maintenance and operating cost when purchasing upfront. Moreover, it also boosts capability, capacity and readiness to serve on 24/7 (twenty-four hours a day and seven days a week) basis. Additionally, the assets should be at least two so that it will have an alternate and will not jeopardize the operation at the time of crisis or even for the normal operation.

In the Nepal Army Aviation airpower, every asset is considered strategically vital. At least two thirds of the available aircraft should be serviceable for operations. For this, it also requires strong logistic back up, maintenance and efficient service in addition to the Government support. To have better visibility, effective tracking, monitoring, managing and overseeing spares, work in progress and aircraft maintenance records should be governed through the Logistics Management System and maintenance applications.

\section{Partnership with Civil Aviation Authority of Nepal}

Army Aviation can establish a formal agreement to consolidate and better equip for the Search and Rescue operation when deemed necessary. In the past, due to topographical features and tough geographical locations it required more than three days to locate the missing aircraft. For instance, Shree Airlines Mi-17 Ghunsa Helicopter Crash in September 2006. This ill-fated helicopter crashed on 23 September 2006 and located on 25 September 2006 i.e., on the third day after the crash. Likewise, Dynasty Air helicopters crashed on 27 February 2019 bodies were able to recover on the second day.

All the airports which are available in Nepal are not in operation. In Nepal, 31 out of 49 airports are in operation, and 18 of them are not in operation. Besides, three of the airports are under construction. These airports are mostly in the hilly and mountainous terrain where there is limited road connectivity and also rugged terrain. In these areas, airports are heavily dependent on-air services for the fast and reliable services like in Mid-Western Region, Karnali Province

And Far Western Region (Sudurpaschima Province). In addition, these two provinces are also less developed. During the monsoon or winter season due to the flood, landslide and snow fall, roads stretching from the South to North are impassable and people need to search air options for passenger, cargo flights and emergency evacuation of patients to the better equipped medical facility. 


\section{Table: 2 Airports in Nepal}

\begin{tabular}{|l|l|l|l|}
\hline \multicolumn{4}{|c|}{ Airports in Operations - 31 } \\
\hline 1 & $\begin{array}{l}\text { Tribhuwan International Airport } \\
\text { (International Airport) }\end{array}$ & 17 & Lamidanda Airport \\
\hline 2 & Biratnagar Airport (Domestic Hub) & 18 & Phaplu Airport \\
\hline 3 & Gautam Buddha Airport (Domestic Hub) & 19 & Rajbiraj Airport \\
\hline 4 & Pokhara Airport (Domestic Hub) & 20 & Ramechhap Airport \\
\hline 5 & Nepalgunj Airport (Domestic Hub) & 21 & Rara Airport \\
\hline 6 & Bajura Airport & 22 & Rumjatar Airport \\
\hline 7 & Bharatpur Airport & 23 & Salle Airport \\
\hline 8 & Bhojpur Airport & 24 & Sanfebagar Airport \\
\hline 9 & Chandragadhi Airport & 25 & Simara Airport \\
\hline 10 & Chaurjahari Airport & 26 & Simikot Airport \\
\hline 11 & Dang Airport & 27 & Surkhet Airport \\
\hline 12 & Dhangadhi Airport & 28 & Tenzing-Hillary (Lukla) Airport \\
\hline 13 & Dolpa Airport & 29 & Tumlingtar Airport \\
\hline 14 & Janakpur Airport & 30 & Taplejung Airport \\
\hline 15 & Jomsom Airport & 31 & Thamkharka Airport \\
\hline 16 & Jumla Airport & \multicolumn{3}{|l|}{} \\
\hline \multicolumn{3}{|l|}{ Airports Not in } & Operation (18) \\
\hline 1 & Baglung Airport & 10 & Langtang Airport \\
\hline 2 & Baitadi Airport & 11 & Mahendranagar Airport \\
\hline 3 & Bajhang Airport & 12 & Manamaya Rai Khanidanda Airport \\
\hline 4 & Darchula Airport & 13 & Manang Airport \\
\hline 5 & Dhorpatan Airport & 14 & Masinechuar Airport \\
\hline 6 & Doti Airport & 15 & Meghauli Airport \\
\hline 7 & Gorkha Airport & 16 & Rolpa Airport \\
\hline 8 & Jiri Airport & 17 & Syangboche Airport \\
\hline 9 & Kangeldanda Airport & 18 & Tikapur Airport \\
\hline & & 3 & Khiji Chandeshwori Airport \\
\hline 1 & Falgunanda Airport & & \\
\hline 2 & Gulmi (Resunga) Airport & Airport under Construction - 3 \\
\hline
\end{tabular}

(Source: Airport Profiles: https://caanepal.gov.np/aerodromes/domestic-airports)

Needless to say, if the private operators could not see profit at particular airports and flow of passenger and cargo is less, the operator stops flying on the non-profit sectors. After some time, due to the lack of operations airports also become non-operational even though it is recently black topped or renovated with the state scarce resource. In order to prevent further ruining and preserving the national property, Civil Aviation and Army Aviation can work under civil enclave so as to make it operational all the time by using the airfield for disaster preparedness, commercial operations, training and emergency operations. 
Command, Leadership and Management Opportunity for the Aviators

Army aviation is an indispensable arm of Nepal Army to project air power strength and advice on the air issues to the higher echelon. Army aviator is also a critical component for the organization. In order to generate capable and effective future Commanders of Army Aviation, in addition to their occupational courses pilot, engineer and other technical stream personnel should be provided Command, Leadership and Management (CLM) level courses equally as other supporting arms.

\section{Service to the Sister Security Forces}

Nepal is a small country and aviation is the expensive field. Even a single security entity is going through several challenges to make all aircraft serviceable, maintain, operate and sustain for all types of operations. Increasing the number of aviation units other than the Army warrants huge capital and current expenditure from the national exchequer. Moreover, by equipping Nepal Army Aviation with more assets to support the aviation requirements of the sister security forces and Provincial Government would be the most economic and the best option for the nation at this time.

\section{Prepositioning of Aircraft at the various location during the Monsoon Season}

Before the onset of disaster especially in the monsoon season, air assets should be positioned at the various locations with the disaster equipment for aerial rescue and evacuation either at the safe location or better medical facility until the Western and Eastern Air Base are fully functional. During the monsoon season, dedicated air assets should be pre-positioned in addition to
Kathmandu and Surkhet at least at Biratnagar, Bharatpur/Pokhara, Dang and Dhangadhi so that all seven provinces will have disaster preparedness and aerial response capability.

\section{Mi-17 size Helipad on Every Village}

At the time of Nepal Earthquake 2015 Sankatmochan Operations, there were difficulties to operate small (Lancer and equivalent) and heavy category (Mi-17 and equivalent) helicopters at the various locations of affected areas. The helicopter was restricted to make either a drop from a height or return to the district headquarter/ main base due to the confined space and obstacles to maneuver safely. Therefore, as a lesson learnt to prepare to effectively operate at the time of mega Earthquakes or any other types of disaster rescue flights, there should be at least one Mi-17 size helipad on every village across the country.

\section{Mission Hardened Air Assets}

In order to face the future challenge army aviation requires versatile air assets that can provide effective close air support, night vision, aerial reconnaissance and surveillance. Additionally, induction of Unmanned Aerial Vehicle (UAV)/Remotely Piloted Aircraft System (RPAS) popularly known as Drone should be procured and used in normal operation of anti- poaching, border surveillance, light cargo transportation and damage assessment in the disaster.

\section{Aviation Friendly Procurement Acts and Rules}

There should be a revisit on existing Government Procurement Act 2063 and regulations in order to make aviation friendly procurement acts and rules so that at the time of emergency or even at the normal 
period i.e., Aircraft on Ground (AOG) ${ }^{2}$, provision should be included to authorize immediate procurement of spares parts from the manufacturers or manufacturer approved vendors. Due to the lack of AOG provision to procure even a minor spare, at times the aircraft are grounded for a long time.

\section{Regular Basic Pilot Training}

Pilot training should be conducted in Nepal on a regular basis to fulfill the requirements for the organization and become self-reliant similar to Combat and Combat Supporting arms officers. This training school should have a vision to train civilians by getting the approval from the Civil Aviation Authority of Nepal and other professional courses for the engineer and other technical personnel.

\section{Aid to Civil Power}

At the time of crisis or Government disobedience or emergency, army aviation should also be prepared to complement aviation related essential services such as Air Traffic Control (ATC) service, refueling operations, ground handling, Aircraft Crash and Rescue Operations on the base/off the base. This also includes the transportation of ballot box and electoral staff during the election (federal, provincial and local) and Government Board Exams question papers in the security sensitive areas.

\section{Mission First Safety Always}

Army aviator has always an obligation and is prepared to carry out the emergency flights round the clock i.e. twenty four hours in a day. They are also capable and proven by profession in the past. At the same time, we

2 Aircraft on Ground is an aviation term requiring urgent action to bring the spares from outside in order to bring aircraft to fly as soon as possible normally within 72 hours. should also be cognizant of the fact that the more we fly the more we get confidence, feel secure and safe to operate as there is no second chance in aviation. If there is less number of operational flying and aviators have not flown to STOL or high altitude for a certain period due to the various reasons, with the quality training, continuation, refresher, familiarization, proficiency check, live exercise, effective monitoring and regular oversight helps to promote mission first safety always in the true spirit.

\section{Conclusion}

Since the establishment, Nepal Army Aviation has proven its capability as one of the indispensable components of Nepal Army with countless number of contributions at normal, disaster and emergency with its limited available air assets, infrastructure, manpower and resources. In the present context also, it is equally required for the prompt rescue, relief, humanitarian and special flights. Besides, development and expansion of civil aviation in Nepal has remained vital for the overall development of the country. Through the robust aviation structure, air assets and expansion in the eastern and western regions of the country shall diversify, decentralize and distribute the national resources to further reach out to the people. Such prompt responses to disasters empower communities and support people in emergencies days and nights. After all, investing in the modernization and better equipping of it, is an investment in the state-owned strategic assets, airpower and national security. At last, but not the

Least, the Government should also need to give enough priority in order to make it robust, agile and nimble for the service to the country, people and organization. 


\section{References}

\section{Books}

Bhandari, K. B. (2009). "Civil-military relations in Nepal's democratic transition”,

Nepal's National Interest. Kathmandu: Sangam Institute.

Kafle, S. K. (2017).“Disaster Early Warning Systems in Nepal: Institutional and Operational", Journal of Geography \& Natural Disasters. Volume 7, Issue 2, Kathmandu.

Shrestha, M. (2000). Nepalese Aviation \& Tourism. Kathmandu: Pramila R. Shrestha.

CAAN (2020). Aviation Safety Report. Kathmandu: Civil Aviation Authority of Nepal.

CAAN (2020). CAAN Report 2019-20. Kathmandu: Civil Aviation Authority of Nepal.

DOR (2018). Statistics of Strategic Road Networks of Nepal. Lalitpur: Department of Roads.

MOHA (2019). Nepal Disaster Report 2019. Kathmandu: Ministry of Home Affairs.

\section{Online Resources}

Becker, K. (2010). Hundreds of Trekkers Stuck In Lukla - Nepal. https://himalman.wordpress. com/2010/11/29/hundreds-of-trekkers-stuckin-lukla-nepal/ accessed on 02 December 2020.

KC, S. (2020). Timeline of Nepal Aviation, glimpse from 1949 to 2020. https://www. aviationnepal.com/timeline-of-nepalaviation-glimpse-from-1949-to-2020/ accessed on 04 December 2020.
Pokharel, D. (2020). Nepal Army flying to Jumla for swab collection and medical supplies transportation. https://www.aviationnepal. com/nepal-army-flying-to-jumla-forswab- collection-and-medical-suppliestransportation/ accessed on 01 December 2020.

Rimal, Shyam, Nepal 24 Hours.Com Online news. Bangladesh Wants To Be Close To Nepal. https://nepal24hours.com/bangladeshwants-to-be-close-to-nepal/ accessed on 05 December 2020.

NA Helicopter Rescues A Delivering Woman. The Rising Nepal, online news of 02 January 2020.https://risingnepaldaily.com/nation/ na-helicopter-rescues-a-delivering-woman, accessed on 09 December 2020.

Chiefs of Nepal Army, Armed Police Force Visit border outpost near Kalapani published on online edition of myRepublica on 17 June 2020. https://myrepublica.nagariknetwork. com/news/chiefs-of-nepal-army-armedpolice-force-visit- border-outpost-nearkalapani/ accessed on 04 December 2020.

Airport Profiles published on official website of Civil Aviation Authority of Nepal. https:// caanepal.gov.np/aerodromes/domesticairports, accessed on 01 December 2020.

Nepali Army Beyond Primary Duties published on https:/www.nepalarmy.mil.np/page/bpd, accessed on 01 December 2020.

Airports of Nepal. https://www.guthi.net/nepalatc/ airports.html\#15.\%20Bhojpur, accessed on 01 December 2020. 
Commercial flights, Nepal Army choppers deployed to evacuate stranded Indian Kailash Mansarovar pilgrims PTI online news on 04 July 2018. https://economictimes.indiatimes. $\mathrm{com} /$ news/politics-and-nation/all-strandedindian-kailash- mansarovar-pilgrimsevacuated-from-nepal/articleshow/64895481. cms, accessed on 03 December 2020.

Janatapati Online News dated 28 February 2019. Bodies of helicopter crash airlifted to Kathmandu. https://en.janatapati.com/newsdetail/622 accessed on 05 December 2020.

Nepal Army MI17 Helicopter Lands in Chhangru of Kalapani Area in Darchula. https:// www.youtube.com/watch?v=LZ9Z46Jsto4, accessed on 04 December 2020

The Gurkha Brigade Association news of 29 March 2016. HRH Prince Harry's visit to Nepal https://www.gurkhabde.com/hrhprince-harrys-visit-to-nepal/, accessed on 05 December 202013.
Death Toll Rises To 29, PM Oli Reached To Bara And Parsa To Take Stock Of Situation. New Spotlight Online news of 1 April 2019. https://www.spotlightnepal.com/2019/04/01/ death- toll-rises-29-pm-oli-reached-bara-andparsa-take-stock-situation/, accessed on 09 December 2020.

Zee News Online Edition 01 August 2005. Nepal takes control of a foreign plane entering its sky without permission. https://zeenews.india. com/news/south-asia/nepal-takes-controlof-a- foreign-plane-entering-its-sky-withoutpermission 232469.html, accessed on 03 December 2020. 